\title{
Adjusting Tax Policy to the Challenges of Digitalization, Inequality and Technological Unemployment
}

\author{
Azamat B. Berberov'a,b and Nikolai S. Milogolov*c,d \\ ${ }^{a}$ Gaidar Institute for Economic Policy \\ Moscow, Russian Federation \\ ${ }^{b}$ Financial University under the Government of the Russian Federation \\ Moscow, Russian Federation \\ ${ }^{c}$ Russian Presidential Academy \\ of National Economy and Public Administration \\ Moscow, Russian Federation \\ ${ }^{d}$ Financial Research Institute under the Ministry of Finance \\ Moscow, Russian Federation
}

Received 27.04.2020, received in revised form 02.09.2020, accepted 13.11.2020

\begin{abstract}
The article is devoted to the problem of tax systems' transformation in the era of digital economic development. The authors highlight the problem of technological unemployment and growing income inequality as the article's primary concern, which they explain using a gap in workers' professionalism and qualifications. The authors highlight various possible consequences for the tax systems of developed and developing countries. Based on this analysis, the authors also consider the prospects for multilateral cooperation as an instrument of economic policy that aims to slow the rate of technological unemployment and the growth of inequality (both between and within countries). Having studied developed and developing countries' economic interests, in their concluding arguments, the authors suggest that a cooperation scenario is currently unlikely, which places the poorest countries' tax systems in an extremely vulnerable position. The final part of this article explores the Russian tax system's adaptation to digital economic challenges. This article was prepared as part of research by state assignment at the Russian Academy of National Economy and Public Administration.
\end{abstract}

Keywords: technological unemployment, tax policy, digital economy, inequality, tax competition, tax cooperation, developing countries, corporate income tax, personal income tax, robot-tax.

Research area: financial policy, tax policy, labor market, employment.

\footnotetext{
(C) Siberian Federal University. All rights reserved

* Corresponding author E-mail address: nmilogolov@nifi.ru, berberov@iep.ru ORCID: 0000-0003-2739-8912 (Berberov); 0000-0001-8858-0182 (Milogolov)
} 
Citation: Berberov, A.B., Milogolov, N.S. (2020). Adjusting tax policy to the challenges of digitalization, inequality and technological unemployment. J. Sib. Fed. Univ. Humanit. Soc. Sci., 13(11), 1710-1722. DOI: $10.17516 / 1997-1370-0677$.

\section{Introduction}

The increasing and continually advancing use of technology in the value creation process has raised broad economic and social challenges. These challenges inevitably pressure tax systems and require comprehensive research in order to be addressed. The most commonly discussed global issues include:

- digitalization's impact on inequality - the digital divide, which is defined as a gap between individuals, households, businesses and geographic areas at different socio-economic levels regarding both their opportunities to access information and communication technologies (ICTs) and their use of the Internet for a wide variety of activities (OECD, 2002);

- digitalization's impact on employment - technological unemployment, which can be defined as unemployment due to the discovery of means of economizing the use of labor surpassing the pace at which we can find new uses for labor (Keyns, 2009); and

- digitalization's impact on tax revenues from corporate income taxation - the inconsistency between the current international tax rules, based on the physical presence of a tax nexus and global virtual businesses (such as e-commerce) that can achieve a significant economic presence in key markets without any physical presence (scale without mass) (Action 1, 2015);

The academic literature has thoroughly analyzed the issues mentioned above in the context of tax policy transformation, but each issue has usually been examined separately from the other issues. The main idea of the current research is that the problems mentioned above cannot be separated from each other because they are closely related, so spillovers occur between them. Therefore, in developing both domestic tax policies and a new international tax architecture for the digitalized world, these issues should be considered comprehensively.

\section{Theoretical Framework}

Accumulated definitions of the digital economy proposed by Organisation for Economic Co-operation and Development (OECD) (2017), United Nations (UN) (Rujoiu, 2019), International Monetary Fund (IMF) (2018), the Australian Government (2013) and Deloitte (2019) show that the digital economy's main productive force is the collection and analysis of large amounts of information through information and communication technologies. Given that about $60 \%$ of the world's population has access to the Internet (Clement, 2019), the digital transformation has primarily affected business models based on processing user data, such as Internet search engines, social networks and electronic platforms for the online commerce of goods and services. In the context of this model, data is exploited primarily for marketing purposes - for example, for targeted advertising. However, technological progress also includes the development of technologies with a very heavy impact on human labor's contribution to a final product. These technologies include advanced robotics, artificial intelligence (AI), the Internet of Things (IoT), cloud computing, big data analysis and 3D printing. In the context of these technologies, industrialized data is used primarily for production purposes - for example, at highly digitalized factories.

Based on the compensatory macroeconomic effects described in the academic literature (Vivarelli, 2007), it can be argued that, in the long term, technological progress has only positive economic consequences. For example, the increasing use of digital technologies creates a large number of opportunities for new human labor applications (World Economic Forum, 2016), which theoretically mitigates the problem of technology displacing labor as a factor of production. However, this theory can be challenged since it is long term-oriented and does not consider the transition period of society's adaptation to new 
technologies. During this period of transition, a significant negative impact on well-being and quality of life for both individuals and society can take place. The difficulties of adaptation relate to the fact that, in the context of digital transformation, more and more skilled human labor is needed. This requirement forms the preconditions for increasing inequality, based on different levels of professional knowledge and skills - the so-called "skill-based divide" (Manyika, 2017). Other destructive factors are also worth mentioning - namely, a significant digital divide, especially in Africa and Latin America (United Nations Conference on Trade and Development, 2019), a general insecurity in workers' rights (International Trade Union Confederation, 2019), growing financial and property inequalities (Oxfam International, 2020), and a general slowdown in the global economy (United Nations Conference on Trade and Development, 2017).

\section{Statement of the Problem}

In this regard, the transformation of the tax system is becoming more relevant as the potential increase in technological unemployment, due to the increasing use of digital technologies, may significantly affect tax revenues which any state is interested in maximizing for many reasons, such as combatting technological unemployment. A key fiscal risk is a decrease in tax revenues from the taxation of labor due to a decrease in labor's contribution to output as a result of technological unemployment, which the results of individual studies have also confirmed, indicating technological unemployment's significant potential (Winick, 2018) - especially for workers engaged in routine activities (Chui et al., 2015; Kapelyushnikov, 2017). Another problem relates to international tax architecture's current basis on the distribution of rights for the taxation of passive income from the cross-border transfer of capital and technology between a "residence" country and a "source" country. "Residence" countries are usually more developed countries with advanced technologies, and they usually have primary and often exclusive rights to tax such profits, while the "source" countries' rights to tax profits are often either limited under international agreements or not fully realized due to a lack of necessary technical competences among their local tax authorities (Tanzi, Zee, 2001). Therefore, the transformation of tax systems could trigger another round of international tax competition for the allocation of digitalized capital since countries' adaptation to the new digital environment will vary, depending on their fiscal characteristics - for example, their level of economic development and government spending, as well as their share of the highly educated and digitally savvy population.

In this regard, the risks associated with tax systems' failure to meet the challenges of digitalization are dramatically increasing. Due to the polarization of income resulting from the digital divide, a new understanding of how tax policies contribute to reducing economic inequality may be needed. In turn, outdated international taxation systems could exacerbate global inequalities between developed and developing countries through the mechanism of international tax competition for mobile capital.

\section{Methodology}

Our research is based on general scientific methods of analysis and synthesis, a systematic analysis of social phenomena and processes and a method of comparison, as well as the study of individual countries' cases. The authors use the concepts of technological unemployment and the digital divide to analyze this phenomenon in the context of tax policy measures and digital transformation cases in developed and developing states. Ultimately, practical proposals for tax reforms in Russia are suggested within this context.

\section{Discussion}

As a result of our analysis of digital-transformation cases in the context of challenges to tax policy and international economic competition, we have identified features that differ between major developed and emerging economies, such as OECD countries and BRICS (Brazil, Russia, India, China, and South Africa), and the poorest developing countries, especially those in Africa. In this regard, tax systems' reform in the digitalization context 
should consider two factors. First, the implementation of tax policy measures in the digitalization context should assume that issues of personal and corporate taxation cannot be considered or reformed separately. This judgment is based on the fact that digitalization significantly changes the existing balance between labor and capital taxation since it significantly affects labor's share in production and employees' level of real wages. Therefore, significant spillovers can arise from any tax reform that adjusts the tax burden onto either capital or labor. These spillovers can arise at either the national or international level, and they include - for example - the domestic substitution of routine labor with technologies and the cross-border transfer of digitalized capital and highly skilled labor. Secondly, special attention should be paid to the international tax system, and political efforts should be directed toward strengthening tax cooperation. International taxation's importance is increasing due to globalization of the world economy and its connectivity through both information and telecommunication systems, increasing data flows and transnational enterprises' value chains, which leads to a "migration" of digitalization's economic effects between the moreand less-developed worlds.

\section{Results: Economies' Digital Transformations in Different Countries}

In our opinion, in developed economies with less government spending and a well-educated, digitally savvy populations, digitalization's negative fiscal effects described above will be less significant. Thus, such states may even reduce taxes on labor and capital in order to attract key drivers of digital value creation (highly qualified workers and intellectual property) to their jurisdictions from higher-tax jurisdictions. Such a tax policy would exacerbate global tax competition.

However, larger economies with large populations, high government spending and high costs of digital transformation may face significant fiscal difficulties due to digital transformation for the reasons mentioned above. This strain can lead to the implementation of "protectionist" fiscal policies in order to address the effects of global digital transformation imported from nearby economic competitors. This kind of scenario can already be seen through the prism of larger EU countries' reaction to the expansion of digital businesses from the United States into their own markets (Asen, 2020), as well as through the revival of the "robot-tax" idea in some countries that either are highly digitalized or have large populations (Table 1).

The characteristics of the transformations of less-developed countries' tax systems, and especially the poorest countries', should be highlighted separately. First, technological unemployment may affect the poorest countries from outside as a result of investments by highly digitalized multinational enterprises (MNEs), which crowd out local economic activities - for example, in agriculture - but do not lead to significant employment increases. Second, the poorest countries' economic role in global value chains often relates to less-valu-

Table 1. Robot-tax: Modern interpretation

\begin{tabular}{|l|c|l|l|}
\hline \multicolumn{1}{|c|}{ Country } & Introduced & \multicolumn{1}{|c|}{ Form } & \multicolumn{1}{c|}{ Focus } \\
\hline $\begin{array}{l}\text { South Korea (Vigliarolo, } \\
\text { 2017) }\end{array}$ & Yes & $\begin{array}{l}\text { Restricted incentives for in- } \\
\text { vestments in technology }\end{array}$ & $\begin{array}{l}\text { Equalization of the tax burden on } \\
\text { human and capital-intensive labor }\end{array}$ \\
\hline Canada (Chan, 2019) & Idea & $\begin{array}{l}\text { Payment of a terminated staff } \\
\text { member's income tax }\end{array}$ & Recruitment of a staff member \\
\hline India (Shankaran, 2019) & Idea & $\begin{array}{l}\text { Limited incentives for invest- } \\
\text { ments in technology }\end{array}$ & $\begin{array}{l}\text { Equalization of the tax burden on } \\
\text { human and capital-intensive labor }\end{array}$ \\
\hline China (Cai, 2018) & Idea & Not specified & $\begin{array}{l}\text { Formation of a universal basic in- } \\
\text { come }\end{array}$ \\
\hline
\end{tabular}

Source: Compiled by the present authors. 
able functions that digital technologies could already replace. Third, the poorest countries have often been characterized by low institutional development and a weak education sector - including the digital literacy context which has caused difficulty for such jurisdictions in attempting to emerge from their challenging socioeconomic situations.

In this regard, the Oxford Martin School notes the growing relevance of the poorest developing countries' search for new economic models - even though technological unemployment is likely to affect developing countries later than developed countries (Frey et al., 2016). In the school's view, the two pillars of the foundation on which new policies should be built are investments in boosting domestic demand and the education sector (Frey et al., 2016). This view has a certain logic, given that the digital economy is characterized by a rapid expansion of new self-employment opportunities via reduced barriers to entry - including for women, people with disabilities, and people living in remote regions (World Bank, 2016). Below are just a few cases that illustrate digitalization's positive effects in the poorest countries (Table 2).

These examples can be viewed as a modern interpretation of one effect of technological transformation, the inflow of investment in new economic sectors leading to the partial absorption of the substituted workers from these sectors that are gradually getting rid of excess labor (Vivarelli, 2007). However, we suggest that merely connecting people from the poorest countries to digital platforms may not be sufficient to combat technological unemployment, especially when the digital revolution would lead to a wider displacement of workers from traditional industries.

The scale of this potential substitution of low-cost labor by technology has been illustrated in the research conducted by the Oxford Martin School (Frey, 2016): developing countries may be at a much higher risk of a technological displacement of labor. The school suggested that the potential for job automation varies from 55 percent in Uzbekistan, 69 percent in India, 77 percent in China and 85 percent in Ethiopia to an OECD average of 57 percent (Frey, 2016). The International Labour Organization (ILO) has a similar view, arguing that 64 percent of jobs in Indonesia, 86 percent in Vietnam, and 88 percent in Cambodia are at risk of displacement - particularly in the textile industry (International Labour Organization, 2019). Therefore, for such jurisdictions, a transformation of the tax system may present a significant challenge. Initially, it should include the development of tax incentives to attract

Table 2. Cases of successful socioeconomic transformation through digital economic models

\begin{tabular}{|c|c|c|}
\hline Example & Region & Comments \\
\hline e-Commerce market (World Bank, 2016) & China & $\begin{array}{l}\text { More than } 10 \text { million jobs created in online shops } \\
\text { and related industries }\end{array}$ \\
\hline $\begin{array}{l}\text { Digital payment system M-Pesa (World Bank, } \\
\text { 2016) }\end{array}$ & Africa & Source of income for over 80,000 of its agents \\
\hline $\begin{array}{l}\text { IT-company Andela (Youth Employment De- } \\
\text { cade, 2017) }\end{array}$ & Africa & $\begin{array}{l}\text { Provision of free online training; the company } \\
\text { plans to train } 100,000 \text { African developers by } \\
2024\end{array}$ \\
\hline $\begin{array}{l}\text { Online platform Farmerline (Food and Agricul- } \\
\text { ture Organization of the United Nations, 2017) }\end{array}$ & Ghana & $\begin{array}{l}\text { Combination of } 200,000 \text { farmers to increase } \\
\text { proximity to markets }\end{array}$ \\
\hline $\begin{array}{l}\text { Women on the Internet (World Bank Group, } \\
\text { 2018) }\end{array}$ & $\begin{array}{l}\text { Kosovo } \\
\text { Region }\end{array}$ & $\begin{array}{l}\text { Creation of new jobs for women via training in } \\
\text { IT skills }\end{array}$ \\
\hline Digital service Samasource (World Bank, 2016) & \multirow{2}{*}{$\begin{array}{l}\text { Poorest } \\
\text { countries }\end{array}$} & \multirow{2}{*}{$\begin{array}{l}\text { Connection of US and UK clients with workers } \\
\text { from the poorest countries, most of whom are } \\
\text { women }\end{array}$} \\
\hline Digital service Rural Shores (World Bank, 2016) & & \\
\hline
\end{tabular}

Source: Compiled by the present authors. 
more foreign investment and technology, which may, however, exacerbate technological unemployment. The solution to this "vicious circle" could be economic policy measures aimed to prevent foreign investors from shifting the tax base without adequate taxation at the source and to create fiscal government funds in order to finance low-skilled workers' adaptation to the new digitalized reality and development of new valuable skills; however, this task would be difficult under the current constraints of tax systems and limited fiscal resources.

\section{Results: International Tax Cooperation's Potential to Resolve the Problem of Adapting Tax Systems to Digitalization Challenges}

Cooperation in taxation is a controversial aspect of international tax rules. On the one hand, the huge number of bilateral tax agreements to eliminate double taxation and prevent fiscal evasion indicates the international tax architecture's maturity. On the other hand, its scope, content and essence can be reasonably criticized today, especially given digital technologies' increasing role in society's economic life. Here are just a couple of key arguments supporting such criticism:

- Bilateral tax treaties, as they are designed today, focus on the international tax problems of the "industrial economy" and are not adapted to the digital reality. The principles laid down in tax treaties do not properly reflect the changing reality of the digitalized world (for example, the role of cross-border flows of data and the lesser importance of a physical presence at market states) (Action 1, 2015);

- The international tax system is incapable of rapid transformation aimed to solve specific problems surrounding the distribution of the tax base, especially between developing and developed countries (one example is the tax revenue losses related to the "brain drain" problem) (Milogolov, Berberov, 2019).

The combination of these factors challenges humanity to rethink the international tax architecture more deeply, considering digital technologies' broad impact on the economy and society. The urgency to search for a new direction in this transformation is also evident in the increasing activity level for tax policy that aims to introduce uncoordinated taxes to digital businesses (Asen, 2020). This policy is reasonable because insufficient budget revenues can lead to social and economic shocks to society, including in the context of retraining technologically ousted citizens. Notably, however, some states also oppose this policy, alleging that it is unfair and that it breaches the principles of global tax and trade rules (Hovet, 2020).

In this regard, international tax cooperation to address technological unemployment is suggested by the authors. An inspiration for this idea can be found in the works of the Dutch trade union leader Edo Fimmen, who suggested concluding international agreements aimed at "slowing down the use of new production methods" (Fimmen, 1924). History repeats itself, given that some experts have argued for the need to redistribute developed states' income to developing states by paying citizens a global universal basic income (Condliffe, 2018). The authors of that proposal do not indicate how such funds would be raised. In this regard, let us improve upon the idea and assume that the mechanism for such collection would be an ephemeral global tax tool (e.g., a global robot tax).

To consider the prospects of such a tax tool, jurisdictions' handling of multilateral agreements should be analyzed. Broekhuijsen (2016) discussed this issue, stating that countries' economic interests were a necessary condition for their entering into cooperative arrangements and that an appropriate consensus among the most influential countries constituted a sufficient condition. From this perspective, developing countries' participation in such cooperative tax agreements - especially among the poorest states - is reasonably economically rational for them. However, in our view, the prospects of such cooperation are not very optimistic, especially given that modern international relations under the conditions of the digital economic transformation are not characterized by equality among countries' bargaining positions. The international tax architecture is controlled by developed OECD countries and major emerging economic powers (e.g., China and India) (Broekhui- 
jsen, 2016), while the poorest countries' economic role is not extensive. At the same time, the generation of digital solutions is currently in the hands of companies from the two largest economies, the United States and China (United Nations Conference on Trade and Development, 2019), for whom the problem of technological labor displacement within their domestic economies is not theoretical, and who are unlikely to be interested in sponsoring the poorest countries' welfare unless such sponsorship leads to additional economic benefits for the sponsors themselves.

Based on this analysis, we believe international tax cooperation that aims at a greater redistribution of tax revenues in favor of the poorest developing countries seems utopian today. In this regard, cooperative mechanisms that aim to encourage research and an exchange of experience to combat technological unemployment, similar to the UN's recommendations (UN Department of Economic \& Social Affairs, 2017) - which, however, do not fundamentally solve this problem for the poorest developing countries - may be the current upper limit of tax cooperation. Developing countries are left to face the indicated problem, which - in our opinion - contradicts Goal No. 9 in the 2030 Agenda of the UN General Assembly (United Nations Sustainable Development Goals, 2015) and relates to the promotion of "sustainable development."

\section{Results: What Should \\ the Russian Federation Do? \\ Directions for the Development of the Tax System}

It should be noted that the Russian Federation's position is unique in many respects. On the one hand, the country is characterized by a large population that is more educated than developing countries' populations. On the other hand, the Russian economy has strong competitive disadvantages, including its main focus on exporting low-value-added goods (such as extracted natural resources), its high level of financial and property inequality, and its large number of industrial monocities. Thus, the state could face problems concerning the tech- nological displacement of its workforce. This potential, in particular, has also been indicated by the results of studies conducted by Zemtsov (2017), McKinsey (Manyika, 2017), The Economist (2018) et cetera.

We tend to proceed from the point of view expressed by the Oxford Martin School (Frey et al., 2016): in the short term, the technological displacement of labor is typical for developed countries, but over the longer term, this process will inevitably affect developing countries, including the Russian Federation. In this regard, Russia has time to develop its own technological adaptation scenario.

In our opinion, when developing Russia's strategy to combat technological unemployment, we should turn to two updated ideas originating from classical political economists. The first of these ideas was originally expressed by the German economist and philosopher Karl Marx, who argued that "the machines are not to blame for freeing people from their livelihoods" (Marx, 1983). The second of these ideas was originally expressed by the British economist Sidney James Webb: "The conversation should not be about whether or not to introduce machines, but about the conditions under which they should be introduced" (Kolokolnikov, 1909). With these ideas in mind, we advocate for a policy that aims to proactively dampen the digital transformation's negative social and economic consequences.

Reforms should not be limited to internal tax policy alone. Transformation processes that align with this new historical challenge should also touch upon international tax policy, especially accounting for tax policies' active transformation in foreign countries. The primary challenge is to support Russian IT companies' activities. This support is necessary to level the tax burden and the playing field for foreign companies with a significant presence in Russia and for local companies, preferably by coordinating the measures introduced with the other Eurasian Economic Union (EAEU) member states. Table 3 shows the revenue potential of taxing foreign digital companies' profits.

As calculations above show, the introduction of such a tax reform would enable a partial 
compensation for the losses resulting from the digital redesign of traditional market segments, such as taxis, as well as the redistribution of revenues in favor of Russian capital and the country's budget - including the context of technologically retraining Russians. This approach requires the development of a corporate taxation methodology; meanwhile, the tax service already has the necessary resources for administration in the digital environment. These resources are indicated, in particular, by the amount of VAT collected from the provision of foreign companies' digitalized services (Table 4).

The second aspect of improving tax policy, in our opinion, should concern the mechanism of personal income taxation. This aspect is necessary because most of this mechanism's revenues, to date, have been collected from people with relatively small incomes. Despite some experts' suggestion that reforming the personal income tax collection mechanism will not yield much revenue or improve social justice (Ageeva, 2017), we consider this approach paradoxical and advocate for increasing the personal income taxation mechanism's progressivity. Such a strategy would enable an offsetting of the wage polarization that has resulted from the transition to new working conditions - the skill-based divide problem.

The third aspect of the reform relates to tax incentives for staff education and retraining. To date, according to Rosstat data (2019), companies' expenses to innovatively retrain employees do not exceed $2 \%$ of the total innovative expenses. Certainly, on the one hand, this fact can be interpreted to suggest that the retraining process is not yet relevant for companies. On the other hand, in the absence of an unambiguous answer to this question, we believe introducing a tax incentive for additional deductions from companies' taxable profits is important in order to encourage companies to invest in retraining employees.

Finally, the high level of international mobility among digital specialists of Russian origin puts reconsidering their tax nexus and reforming tax residence criteria; to date, these aspects are elementarily simple and do not reflect the tax nexus of the "drained brain" with the country of origin of these mobile specialists (Milogolov, Berberov, 2019).

The subject for a wider discussion is the introduction of some form of tax on ro-

Table 3. Estimation of additional tax income from the taxation of IT companies' 50 largest representative offices (2018)

\begin{tabular}{|c|c|}
\hline Indicator & Value \\
\hline Revenue & 967.1 billion rubles \\
\hline Average profitability (2017) & $\sim 17.6 \%$ \\
\hline Profit & 170.2 billion rubles \\
\hline Corporate income tax & $\sim 34$ billion rubles \\
\hline
\end{tabular}

Source: Compiled by the present authors based on TAdviser (2019) data.

Table 4. Volume of VAT collected and number of companies

\begin{tabular}{|c|c|c|}
\hline Year & Volume of VAT (billion rubles) & Number of companies \\
\hline 2017 & $\sim 9.4$ & 131 \\
\hline 2018 & $\sim 12$ & 203 \\
\hline 2019 & $\sim 47.5$ & 2,168 \\
\hline 2020 & - & 2,209 \\
\hline
\end{tabular}

Source: Compiled by the present authors on the basis of research by Bryzgalova (2019). 
bots, which may have various forms. Alexei Kudrin, former head of the board at the Center for Strategic Research, stated that "an income tax on robots would mean a tax on technological progress," while the Russian Federation faces the opposite challenge (Feynberg, 2017). However, Kudrin also pointed to the following trend: as a result of robotization, fast-growing companies' profits are also growing rapidly, and consequently, budget funds for citizens' technological retraining should be taken from these companies' funds (Feynberg, 2017). In this regard, in our opinion, the Russian tax system can show the world its positive version of the tax on robots that aims to create incentives to reinvest the profits of businesses with a high level of digitalization. One element of such a measure could be limiting the deduction of expenses for the use of foreign technologies from taxable profits at a reasonable level in order to stop profits from shifting through royalty payments to low-tax jurisdictions.

\section{Conclusion}

The following three points are important to note:

1) With digital technologies' increasing penetration into society and the economy, increasing technological unemployment and growing inequality may become a problem for many countries around the world. In this context, the search for areas of transformation for tax systems at the national and international levels is becoming more relevant. The design of tax reforms depends on states' unique socioeconomic characteristics. However, in our opinion, the question of how the poorest developing countries' tax systems will adapt to these new conditions remains open due to these countries' inherent fiscal limitations.

2) The development of a new instrument for international tax cooperation could contribute to a coordinated transformation of tax systems. However, an analysis of the prerequisites for jurisdictions' introduction of such mechanisms shows that, to date, such an initiative is unlikely to be feasible due to states' different economic interests. In this regard, given the potential for increased technological unemployment, the recommended tax reform trajectory for the poorest states' tax systems remains uncertain.

3) The Russian Federation's situation is unique in many ways. On the one hand, the Russian population is highly educated. On the other hand, unfortunately, Russia cannot yet be classified as a highly developed country. We propose the following tax policy measures for Russia:

- leveling the playing field in corporate income tax burdens for domestic and foreign digital businesses;

- introducing a reform that aims to increase personal income taxation's progressivity and distributional potential, as well as changes to individuals' tax residence criteria;

- developing a system of tax incentives that aims to encourage employee retraining; and

- determining how to introduce a non-classical version of the tax on robots in order to encourage the reinvestment of profits in the Russian economy and prevent profit-shifting.

\section{References}

Action 1 Tax Challenges Arising from Digitalisation (2015). OECD. Available at: https://www.oecd. org/tax/beps/beps-actions/action1/

Action 12 Mandatory Disclosure Rules (2015). OECD. Available at: https:/www.oecd.org/tax/beps/ beps-actions/action12/

Ageeva, O. (2017). Analitik FNS otsenil vozmozhnye poteri biudzheta iz-za otmeny NDFL dlia bednykh [An analysis of the FTS estimated possible budget losses due to the abolition of PIT for the poor]. RBC. Available at: https://www.rbc.ru/economics/27/02/2020/5e5799149a7947a3a4023bf3

Asen, E. (2020). Digital Services Taxes in Europe. Available at: https://taxfoundation.org/digital-tax-europe-2020/ 
Australian Government (2013). The Concept of the Digital Economy. Available at: https://www.alrc. gov.au/publication/copyright-and-the-digital-economy-dp-79/3-policy-context-of-the-inquiry/the-concept-of-the-digital-economy/

Broekhuijsen, D., Vording H. (2016). The Multilateral Tax Instrument: How to Avoid a Stalemate on Distributional Issues? In British Tax Review, 1 (2016), 39-61.

Bryzgalova, E. (2019). Kompanii zaplatili 12 mlrd rublei "naloga na Google [Companies have paid RUB 12 billion in "Google tax"]. Vedomosti. Available at: https://www.vedomosti.ru/technology/articles/2019/06/14/804214-naloga-na-google

Cai, J. (2018). Tax the Terminator: Chinese Adviser Calls for Levy to Stop Robots Taking Over the Workplace. Available at: https://www.scmp.com/news/china/economy/article/2136613/robots-set-overtakehumans-range-work-tasks-10-20-years-top

Chan, C. (2019). Elizabeth May Proposes 'Robot Tax' to Prepare for Future of Automation. Available at: https://vancouversun.com/news/local-news/green-partys-elizabeth-may-proposes-robot-tax-to-preparefor-future-of-automation

Chui, M., Manyika, M., Miremadi, M. (2015). Four Fundamentals of Workplace Automation. McKinsey. Available at: https://www.mckinsey.com/business-functions/mckinsey-digital/our-insights/four-fundamentals-of-workplace-automation

Clement, J. (2019). Internet Usage Worldwide - Statistics \& Facts. Available at: https://www.statista. com/topics/1145/internet-usage-worldwide/

Condliffe, J. (2018). Developing Countries May Need Their Own Strategies to Cope With Job-Taking Robots. Available at: https://www.nytimes.com/2018/07/09/business/dealbook/automation-developing-world.html

Deloitte (2019). What Is Digital Economy? Available at: https://www2.deloitte.com/mt/en/pages/technology/articles/mt-what-is-digital-economy.html

Feynberg, A. (2017). Kudrin vystupil protiv idei oblagat' nalogami trud robotov [Kudrin opposed the idea of taxing robot labor]. Available at: https://www.rbc.ru/economics/27/02/2017/58b3d2c99a7947bbb297e381

Fimmen, E. (1924). Burzhuaznaia i proletarskaia Evropa [Bourgeois and proletarian Europe]. Moscow, Soviet Trade Unions Publ. p. 134.

Food and Agriculture Organization of the United Nations (2017). Farmerline, the Company with the Mission to Transform Farmers into Successful Entrepreneurs. Available at: http://www.fao.org/e-agriculture/news/farmerline-company-mission-transform-farmers-successful-entrepreneurs

Frey, C.B., Osborne, M.A., Holmes, C. (2016). Technology at Work v 2.0. The Future Is Not What It Used to Be: Report by Oxford Martin School and Citi Group. Available at: https://www.oxfordmartin.ox.ac. uk/downloads/reports/Citi_GPS_Technology_Work_2.pdf

Hovet, J. (2020). U.S. Warns of Possible Counter-Measures against Czech Digital Tax. Available at: https://www.reuters.com/article/us-europe-digitaltax-czech/u-s-warns-of-possible-counter-measuresagainst-czech-digital-tax-idUSKBN1ZN0ZN

IMF (2018). Measuring the Digital Economy. Available at: https://www.imf.org/en/Publications/Policy-Papers/Issues/2018/04/03/022818-measuring-the-digital-economy

International Labour Organization (2019). The Future of Work in Textiles, Clothing, Leather and Footwear. ILO, Geneva. Available at: https://www.ilo.org/wcmsp5/groups/public/---ed_dialogue/---sector/documents/publication/wcms_669355.pdf

International Trade Union Confederation (2019). ITUC Global Rights Index. Available at: https://www. ituc-csi.org/IMG/pdf/2019-06-ituc-global-rights-index-2019-report-en-2.pdf

Kapelyushnikov, R.I. (2017). Tekhnologicheskii progress - pozhiratel' rabochikh mest? [Is technological progress a "jobs eater"?]. Available at: https://polit.ru/article/2017/12/03/labour_market/

Keynes, J.M. (2009). Economic Possibilities for Our Grandchildren (Afterword by D. Shestakov). In Voprosy Ekonomiki [Economic Issues], (6), 60-69. (In Russian). DOI: https://doi.org/10.32609/0042-87362009-6-60-69 
Kolokolnikov, P.N. (1909). Professional'noe dvizhenie i soiuzy v Rossii [Professional movement and unions in Russia]. Saint-Petersburg, the Printing House of the "Ekateringof Printing Association," p. 41.

Manyika, J., Chui, M., Miremadi, M., Bughin, J., George, K., Willmott, P., Dewhurst, M. (2017). Harnessing Automation for a Future that Works. Report by McKinsey. Available at: https://www.mckinsey.com/ featured-insights/digital-disruption/harnessing-automation-for-a-future-that-works

Marx, K. (1983). Kapital. Kritika politicheskoi ekonomii. Tom pervyi, kniga 1: process proizvodstva kapitala [Capital. Criticism of Political Economy. Volume One, Book 1: Capital Production Process]. Moscow, Politizdat Publ. p. 3883.

Milogolov, N., Berberov, A. (2019). Brain Drain \& Tax Competition: Do We Need Another BEPS? In Anali Pravnog Fakulteta U Beogradu [Annals of the Faculty of Law in Belgrade], 67/4, 200-237.

OECD (2002). Glossary of Statistical Terms. Available at: https://stats.oecd.org/glossary/detail.as$\mathrm{p} ? \mathrm{ID}=4719$

OECD (2017). OECD Digital Economy Outlook. OECD Publishing, Paris. DOI: http://dx.doi. org/10.1787/9789264276284en. Available at: https://espas.secure.europarl.europa.eu/orbis/sites/default/ files/generated/document/en/9317011e.pdf

Oxfam International (2020). World's Billionaires Have More Wealth than 4.6 Billion People. Available at: https://www.oxfam.org/en/press-releases/worlds-billionaires-have-more-wealth-46-billion-people

Rosstat (2019). Zatraty na tekhnologicheskie innovatsii organizatsii po vidam innovatsionnoi deiatel'nosti po subyektam Rossiiskoi Federatsii [Expenditures on technological innovations of organizations by type of innovation activity by regions of the Russian Federation]. Available at: http://old.gks.ru/wps/ $\mathrm{wcm} /$ connect/rosstat main/rosstat/ru/statistics/science and innovations/science/\#

Rujoiu, O.I. (2019). The Digital Economy. In "Ovidius" University Annals Economic Sciences Series. Volume XIX, Issue 1 /2019. p. 299-302.

Shankaran, Sh. (2019). India Needs to Pursue Its Own Version of a "Robot Tax." Available at: https:// timesofindia.indiatimes.com/blogs/cash-flow/india-needs-to-pursue-its-own-version-of-a-robot-tax/

TAdviser (2019). Ranking TAdviser: 50 samykh dokhodnykh predstavitel'stv inostrannykh IT-kompanii $v$ Rossii [TAdviser Ranking: 50 most profitable offices of foreign IT companies in Russia] Available at: tadviser.ru/index.php/Статья:Рейтинг_TAdviser:_Самые_доходные_представительства_иностранных_ ИТ-компаний в России

Tanzi, V, Zee, H. (2001). Tax Policy for Developing Countries. International Monetary Fund. Available at: https://www.imf.org/external/pubs/ft/issues/issues27/

The Economist (2018). The automation readiness index. Who is ready for the coming wave of automation? Available at: http://www.automationreadiness.eiu.com/static/download/PDF.pdf

UN Department of Economic \& Social Affairs (2017). The Impact of the Technological Revolution on Labour Markets and Income Distribution. Available at: https://www.un.org/development/desa/dpad/ wp-content/uploads/sites/45/publication/2017_Aug_Frontier-Issues-1.pdf

World Economic Forum (2016). The Future of Jobs Employment, Skills and Workforce Strategy for the Fourth Industrial Revolution. Available at: http://www3.weforum.org/docs/WEF_FOJ_Executive_Summary_Jobs.pdf

United Nations Conference on Trade and Development (2017). Roboty nastupaiut: Organizatsiia Obyedinennykh Natsii preduprezhdaet ob opasnosti sovmeshcheniia avtomatizatsii proizvodstva s merami zhestkoi ekonomii dlia khorosho oplachivaemykh rabochikh mest vo vsem mire [The robots are coming: The United Nations is warning of the danger of combining industrial automation with austerity measures for well-paid jobs around the world] Available at: https://unctad.org/en/PressReleaseLibrary/PR17027_ru_ TDR_robots.pdf

United Nations Conference on Trade and Development (2019). Digital Economy Report. Available at: https://unctad.org/en/PublicationsLibrary/der2019_en.pdf

United Nations Sustainable Development Goals (2015). Transforming Our World: The 2030 Agenda for Sustainable Development. Available at: https://sustainabledevelopment.un.org/post2015/transformingourworld 
Vigliarolo, B. (2017). South Korea 'Robot Tax' Is No Tax at All; It's a Warning of Looming Automation Crisis. Available at: https://www.techrepublic.com/article/south-korea-robot-tax-is-no-tax-at-all-its-awarning-of-looming-automation-crisis/

Vivarelli, M. (2007). Innovation and Employment: A Survey. IZA Discussion Paper No. 2621. Available at: http://ftp.iza.org/dp2621.pdf

Winick, E. (2018). Every Study We Could Find on What Automation Will Do to Jobs, in One Chart. Available at: https:/www.technologyreview.com/s/610005/every-study-we-could-find-on-what-automation-will-do-to-jobs-in-one-chart/

World Bank Group (2016). Tsifrovye dividendy [Digital dividends]. Available at: http://documents. worldbank.org/curated/en/224721467988878739/pdf/102724-WDR-WDR2016Overview-RUSSIAN-WebRes-Box-394840B-OUO-9.pdf

World Bank Group (2018). Framing the Future of Work. Available at: http://documents.worldbank.org/ curated/en/806971539845535746/pdf/130983-REVISED-WB-JobsNote6-web.pdf

Youth Employment Decade (2017). Andela, the Start-Up that Trains and Hires New African Talents. Available at: http://www.youthemploymentdecade.org/en/repor/andela-the-start-up-that-trains-and-hiresnew-african-talents/

Zemtsov, S. (2017). Roboty i potentsial'naia tekhnologicheskaia bezrabotitsa v regionakh Rossii: opyt izucheniia i predvaritel'nye otsenki [Robots and potential technological unemployment in Russia's regions: study experience and preliminary estimates]. In Vorposy Ekonomiki [Economic Issues], (7/2017), 1-16. 


\title{
Адаптация налоговой политики \\ к вызовам цифровизации, неравенства \\ и технологической безработицы
}

\author{
А.Б. Берберов ${ }^{\mathrm{a}, \text { б, Н.С. Милоголов }}{ }^{\text {, г }}$ \\ ${ }^{a}$ Институт экономической политики им. Е.Т. Гайдара \\ Российская Федерачия, Москва \\ ${ }^{6}$ Финансовый университет при Правительстве РФ \\ Российская Федерачия, Москва \\ ${ }^{8}$ Российская академия народного хозяйства \\ и государственной службы при Президенте Российской Федераџии \\ Российская Федерачия, Москва \\ 'Научно-исследовательский финансовый институт \\ Министерства финансов Российской Федерации \\ Российская Федераиия, Москва
}

\begin{abstract}
Аннотация. Статья посвящена проблеме трансформации налоговых систем в эпоху цифрового развития экономики. В качестве основной проблемы авторы выделяют проблему технологической безработицы и растущего неравенства доходов, объясняемого разрывом в профессионально-квалификационном уровне работников. Авторы выделяют различные возможные последствия для налоговых систем развитых и развивающихся государств. Исходя из этого авторы также рассматривают перспективы многостороннего сотрудничества как инструмента экономической политики, направленного на замедление темпов технологической безработицы и роста неравенства (как между странами, так и внутри них). Изучив экономические интересы развитых и развивающихся государств при заключении соглашений, авторы предполагают, что такой сценарий сотрудничества в настоящее время вряд ли является реальным, он поставит налоговые системы беднейших государств в крайне уязвимое положение. Заключительная часть статьи посвящена вопросам адаптации российской налоговой системы к вызовам цифровой экономики.
\end{abstract}

Ключевые слова: технологическая безработица, налоговая политика, цифровая экономика, неравенство, налоговая конкуренция, налоговая кооперация, развивающиеся страны, налог на прибыль, налог на доходы физических лиц, налог на роботов.

Научная специальность: 08.00.00 - финансовая политика, налоговая политика, рынок труда, трудоустройство. 